\title{
Factors Affecting the Solubility of Calcium Pyrophosphate Dihydrate Crystals
}

\author{
Robert M. Bennett, James R. Lehr, and Daniel J. McCarty \\ From the Section of Arthritis and Metabolism, Department of Medicine, \\ University of Chicago, Chicago, Illinois 60637
}

A в S T R A C T The solubility of triclinic calcium pyrophosphate dihydrate (CPPD) crystals was measured under varying conditions using ${ }^{{ }^{45}} \mathrm{Ca}$-labeled crystals, expressing solubility as micromoles per liter of ${ }^{45} \mathrm{Ca}$ in solution. In a $0.1-\mathrm{M}$ Tris- $\mathrm{HCl}$ buffer $\mathrm{pH} 7.4$, the solubility of accurately sized CPPD crystals $(37-20 \mu \mathrm{m})$ was $60 \mu \mathrm{M}$ with maximal solubility being attained after about $8 \mathrm{~h}$ incubation at $37^{\circ} \mathrm{C}$. Reduction in crystal size, decrease in $\mathrm{pH}$, increase in ionic strength, $\mathrm{Mg}^{++}$, citrate, and albumin all increased solubility. The most marked effects on solubility occurred when changing the calcium concentration or by enzymatic hydrolysis of inorganic pyrophosphate to orthophosphate. It was found that decreasing the ionized calcium level below $5 \mathrm{mg} / 100$ $\mathrm{ml}$ resulted in a progressive enhancement of solubility. The observed solubility-enhancing effects of albumin could be explained solely on its calcium-binding ability and thereby, altered ionized calcium level. Diffusible calcium in synovial fluid was only $40 \%$ of the total calcium concentration, which means most joint fluids are normally near the critical concentration of $5 \mathrm{mg} / 100$ $\mathrm{ml}$ of ionized calcium, below which solubility is enhanced. During surgery, especially parathyroidectomy, calcium levels fall, favoring dissolution of CPPD crystals. We speculate that the slight decrease in crystal size during dissolution frees them from their cartilaginous mold, resulting in a dose-dependent inflammatory reaction as they are "shed" into the joint space. Crystal shedding may be reinforced by the modest fall in joint fluid $\mathrm{pH}$ accompanying the inflammatory response.

Dr. Lehr's present address is the Fundamental Research Branch, Division of Chemical Development, Tennessee Valley Authority, Muscle Shoals, Ala. 35660. Dr. McCarty is presently with the Department of Medicine, The Medical College of Wisconsin, Milwaukee, Wisc. 53226.

Received for publication 13 February 1975 and in revised form 4 August 1975.

\section{INTRODUCTION}

Over a decade has passed since the initial association of calcium pyrophosphate dihydrate (CPPD) ${ }^{1}$ crystals $\left(\mathrm{Ca}_{2} \mathrm{P}_{2} \mathrm{O}_{7}\right)$ with a gout-like arthritis (1). The articular inflammatory response includes the phagocytosis of intra-articular CPPD crystals by polymorphonuclear leukocytes with the subsequent release of lysosomal enzymes (1-3). In many patients developing pseudogout, CPPD deposits are seen radiologically in both hyaline and fibrocartilage, and we have assumed that the crystals found in pseudogout joint fluid originate from these preformed deposits, but there is no definitive evidence on this point. The mechanism of this cartilaginous crystal deposition remains obscure, but is found more commonly in patients with hyperparathyroidism (4) and hemochromatosis (5). More recently, elevated levels of inorganic pyrophosphate $\left(\mathrm{PP}_{1}\right)$ have been found in the synovial fluid of patients with pseudogout (6-9); during an acute episode, the $P_{1}$ level is paradoxically reduced (9).

As synovial fluid levels of $\mathrm{PP}_{1}$ are higher than in plasma $(6,8,9)$, it is likely that $\mathrm{PP}_{1}$ originates from within the joint. It could arise either from the dissolution of CPPD crystals or as a metabolic by-product of joint tissue metabolism. A knowledge of the solubility of CPPD crystals under various conditions and the rate of attaining equilibrium is of importance in resolving this issue. Moreover, some recent clinical observations (10) have indicated that factors increasing the solubility of CPPD crystals may be of importance as a "trigger" to the acute episode of pseudogout.

This present investigation is an extension of our previous work on CPPD crystal solubility (7). The use of

\footnotetext{
${ }^{1}$ Abbreviations used in this paper: ACD, acid citrate dextrose; CPPD, calcium pyrophosphate dihydrate; SP, simulated plasma.
} 
${ }^{45}$ Ca-labeled CPPD crystals permitted precise measurement of even small increments in solubility.

\section{METHODS}

Gencral. Acid-washed glassware or disposable plastic ware was used. All solutions were prepared in doubly distilled, deionized water. Salts used to prepare standard solutions were stored over anhydrous $\mathrm{CaSO}_{4}$ in a vacuum desicator. All solutions were made up in either $0.1 \mathrm{M}$ Tris$\mathrm{HCl}$ buffer, $\mathrm{pH} 7.4$, or a protein and calcium-free simulated plasma, $\mathrm{pH} 7.4,\left(100 \mathrm{ml}\right.$ containing $\mathrm{NaCl}, 14 \mathrm{mg} ; \mathrm{K}_{2} \mathrm{HPO}_{4}$, $13.4 \mathrm{mg}$; and $\mathrm{NaH}_{2} \mathrm{PO}_{4}, 2.7 \mathrm{mg}$ ) hereafter designated SP. Incubation was performed at $37^{\circ} \mathrm{C}$ in a Dubnoff metabolic shaker. All centrifugation was done at $37^{\circ} \mathrm{C}$ in a Sorvall RC-2 centrifuge (Ivan Sorvall, Inc. Norwalk, Conn.) unless otherwise specified.

The following antimicrobial and antifungal agents were added to each $30 \mathrm{ml}$ of solution: penicillin $10,000 \mathrm{U}$, streptomycin $100 \mathrm{mg}$, amphotericin B $2.5 \mathrm{mg}$.

Radioactive labeled CPPD crystals. Triclinic CPPD crystals were prepared in vitro by a modification of the method of Brown et al. (11) with the addition of ${ }^{45} \mathrm{Ca}$ (New England Nuclear, Boston, Mass.) to give a specific activity of approximately $0.1 \mu \mathrm{Ci} / \mathrm{mg}$. After synthesis, the crystals were washed once in $0.1 \mathrm{M}$ Tris- $\mathrm{HCl}$ buffer $\mathrm{pH}$ 7.4 for $2 \mathrm{~h}$ in a mass/volume ratio of $100 \mathrm{mg} / 2 \mathrm{ml}$.

After washing, the suspension was gently centrifuged, washed twice with a small volume of distilled water, and the crystal dried at $180^{\circ} \mathrm{C}$ overnight before storing over anhydrous $\mathrm{Ca}_{2} \mathrm{SO}_{4}$ in a vacuum desiccator. This washing step effectively removed some highly soluble ${ }^{45} \mathrm{Ca}$ surface contaminates that were present in small amounts.

The crystals were examined using compensated polarizing light microscopy to determine the uniformity of morphological and optical properties (12). Previous X-ray diffraction studies had shown that crystals prepared in this way were biaxial, triclinic forms of CPPD (11), and similar to natural crystals (13).

Three accurately weighed samples of $\left({ }^{15} \mathrm{Ca}\right) \mathrm{CPPD}$ crystals were dissolved in $0.5 \mathrm{ml}$ of $0.5 \mathrm{~N} \mathrm{HCl}$ and counted in $10 \mathrm{ml}$ of Bray's solution. The mean specific activity of these standards was used throughout the study to translate counts per minute ${ }^{45} \mathrm{Ca}$ in the supernate into moles of $\mathrm{Ca}$ (and $\left.\mathrm{PP}_{1}\right)$ dissolved. Solubility was expressed as micromolar concentration of crystal-derived calcium.

Experimental design. The radioactive crystals were sieved to obtain crystals of three sizes: $<20 \mu \mathrm{m}$, between 20 and $37 \mu \mathrm{m}$ and $>37 \mu \mathrm{m}$, (Endecotts Filters, London SW19).

In each experiment, a constant mass/volume (5 mg CPPD to $30 \mathrm{ml}$ solution) was maintained, using a $100-\mathrm{ml}$ conical flask containing a magnetic stirrer.

After the addition of the ${ }^{45} \mathrm{Ca} C P P D$, the flask was removed at intervals timed with a stopwatch and the contents magnetically stirred to a uniform suspension. $1 \mathrm{ml}$ of this suspension was passed through a $0.45-\mu \mathrm{m}$ Millipore filter (Millipore Corp., Bedford, Mass.) to remove the crystals; $0.5 \mathrm{ml}$ of the filtrate was then counted.

The effects of crystal size, $\mathrm{pH}$, ionic strength, $\mathrm{Ca}^{++}, \mathrm{PP}_{1}$, $\mathrm{P}_{\mathrm{i}}$, albumin, citrate, $\mathbf{M g}^{++}$, and synovial fluid on solubility were determined.

Verification of methodology. Three major concerns were: (a) Do the radioactive CPPD crystals behave in the same way as nonradioactive CPPD crystals, or does the insertion of a ${ }^{45} \mathrm{Ca}$ atom affect the solubility? (b) Does the $0.45-\mu \mathrm{m}$ filter completely eliminate all microcrystals? (c) In experiments in which there is calcium in the bathing medium, is there a significant exchange of $\mathrm{Ca}$ for ${ }^{45} \mathrm{Ca}$ calcium at the crystal surface?

The first problem was tested by comparing the solubility of the radioactive crystals $(20-37 \mu \mathrm{m})$, using ${ }^{45} \mathrm{Ca}$ going into solution, to the solubility of similarly sized nonradioactive crystals, using a modification of the method of Chen et al. (14) to measure $\mathrm{P}_{1}$ produced by hydrolysis of $\mathrm{PP}_{1}$. In this modification, $50 \mu 1$ of $4.4 \mathrm{~N} \mathrm{HCl}$ was added to $150 \mu \mathrm{l}$ of the filtrate (from the crystal suspension) and boiled in a tightly sealed screw-capped tube for $60 \mathrm{~min}$. After cooling, $10 \mu \mathrm{l}$ of $6.5 \% \mathrm{wt} / \mathrm{vol}$ ammonium molybdate was added, and during continuous mixing on a Vortex mixer (Scientific Industries, Inc., Queens Village, N. Y.), $50 \mu \mathrm{l}$ of $6.5 \%$ (wt/vol) ascorbic acid was slowly addecl. After incubation at $45^{\circ} \mathrm{C}$ for $50 \mathrm{~min}$ the OD was measured in a Beckman DU spectrophotometer (Beckman Instruments, Inc., Fullerton, Calif.) equipped with a Gilford model 222 absorbance indicator (Gilford Instrument Laboratories, Inc., Oberlin, Ohio). Standard $\mathrm{P}_{\mathrm{i}}$ solutions, 5-50 $\mu \mathrm{M}$, and a reagent blank were subjected to the same procedure.

The second problem was tested by differential density centrifugation (Fig. 1). $800 \mu \mathrm{l}$ of the filtrate from the crystal suspension was divided into two portions: (a) 200 $\mu \mathrm{l}$ was counted directly $(b), 600 \mu \mathrm{l}$ was divided into two equal portions; $300 \mu \mathrm{l}$ of carbon tetrachloride $\left(\mathrm{CCl}_{4}\right)$ was added to one portion. Both were centrifuged $(20,000 \mathrm{~g}$ for $2 \mathrm{~h}$ ) and $200 \mu \mathrm{l}$ of each supernate counted. A further $200 \mu \mathrm{l}$ was carefully pipetted off, and the remaining $\mathrm{CCl}_{4}$ evaporated to dryness; $0.5 \mathrm{ml}$ of $0.5 \mathrm{~N} \mathrm{HCl}$ was added and counted as before. A control experiment was done without prior filtration of the crystal suspension and the results are shown in parentheses in Fig. 1.

The third problem was probed by an isotopic exchange experiment. Intermediate size nonradioactive CPPD crystals were washed and heated as previously described: $13 \mathrm{mg}$ $(44.82 \mu \mathrm{mol})$ of crystals was incubated with $5 \mathrm{ml}$ of $0.1 \mathrm{M}$ Tris- $\mathrm{HCl}$ buffer $\mathrm{pH} 7.2$, containing $0.2 \mu \mathrm{mol}$ of carrier-free ${ }^{45} \mathrm{Ca}$ (sp act $26 \mu \mathrm{Ci} / \mu \mathrm{mol}$ of calcium), over $48 \mathrm{~h}$ at $37^{\circ} \mathrm{C}$ in a Dubnoff metabolic shaker. A control omitting the nonradioactive CPPD crystals was treated similarly. At timed intervals, the container was removed and the contents stirred magnetically to a uniform suspension. $1 \mathrm{ml}$ of this suspension was passed through a $0.45-\mu \mathrm{m}$ Millipore filter and the crystals washed with $2-\mathrm{ml}$ aliquots of the Tris- $\mathrm{HCl}$ buffer until no radioactivity was detected in the filtrate. The Millipore filter was then carefully removed from its holder and dried in an oven at $37^{\circ} \mathrm{C}$. Sequential weighing determined that after $24 \mathrm{~h}$ it was free of all moisture. Its weight after $24 \mathrm{~h}$ was compared to its original dry weight and the difference was taken to represent the mass of filtered CPPD crystals. The control was similarly treated. The dried filters were transferred to counting vials and $0.5 \mathrm{ml}$ of $0.5 \mathrm{~N} \mathrm{HCl}$ added and counted in $10 \mathrm{ml}$ of Bray's solution. The specific activity of the filtered crystals and hence the exchange of ${ }^{45} \mathrm{Ca}$ with nonradioactive $\mathrm{CPPD}$ was calculated from these results.

Treatment of protein-containing solutions. Human serum albumin was dialyzed against SP for 3 days to remove most of the bound calcium. The protein concentration of the dialysate was measured by the biuret method (15); and calcium determined by flame photometry, using a PerkinElmer model 303 atomic absorption spectrophotometer as described in the Perkin-Elmer manual (Perkin-Elmer Corp., Norwalk, Conn.). Appropriate additions of $\mathrm{Ca}^{++}$(in the form of anhydrous $\mathrm{CaCl}_{2}$ ) were added as indicated. Synovial fluids were similarly treated. After $48 \mathrm{~h}$ of a solubility experiment, equilibrium dialysis was performed at $37^{\circ} \mathrm{C}$ 


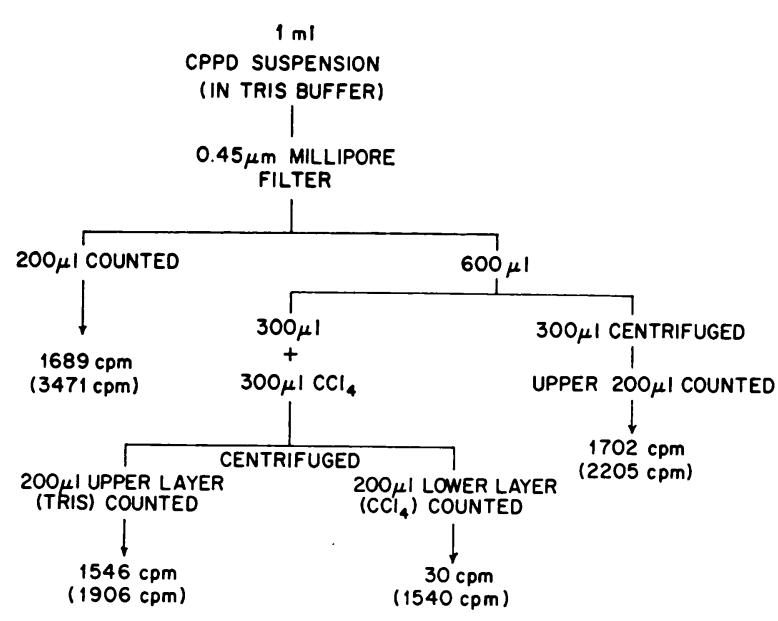

FIGURE 1 Verification of the $0.45-\mu \mathrm{m}$ Millipore filter technique. The counts in the supernate after centrifugation approximate those of the unspun fluid, and after differential centrifugation employing carbon tetrachloride negligible counts are registered in the nonaqueous phase. Bracketed numbers are counts per minute in a control experiment without prior filtration.

for $1 \mathrm{~h}$ in a plexiglas chamber of $1 \mathrm{ml}$ capacity (Chemical Rubber Co. Apparatus, Cleveland, Ohio), separated by dialysis membrane (pore diameter $4.8 \mathrm{~nm}$, Fisher Scientific Co., Pittsburgh, $\mathrm{Pa}$.), and prepared according to the method of Brewer et al. (16). 1-ml aliquot of the filtrate was dialyzed against $1 \mathrm{ml}$ of $\mathrm{SP}$ for $1 \mathrm{~h}$ at $37^{\circ} \mathrm{C}$. Prior ${ }^{45} \mathrm{Ca}$ tracer experiments had shown free calcium equilibrated within $20 \mathrm{~min}$.

The total calcium content in each chamber was measured by atomic absorption flame spectrophotometry and a 100- 1 aliquot from each was counted for ${ }^{45} \mathrm{Ca}$.

10 synovial fluids ( $\mathrm{pH}$ adjusted to 7.4) were similarly dialyzed, with the difference that $10 \mu \mathrm{l}$ of a ${ }^{45} \mathrm{Ca}$ solution $(20,000 \mathrm{cpm})$ was introduced into the SP side of the dialysis chamber. Again the distribution of bound and free calcium was determined both by atomic absorption and by radioactivity distribution.

Estimation of hydrolysis of $P P_{1}$. This was routinely estimated in all experiments at 24 and $48 \mathrm{~h}$. A 2-ml aliquot of the original solution was incubated separately with the addition of $100 \mu \mathrm{l}$ of ${ }^{32} \mathrm{P}^{32} \mathrm{P}_{1}$ (New England Nuclear) with a specific activity of approximately $800 \mu \mathrm{Ci} / \mu \mathrm{mol}$. Nonradioactive synthetic crystals of the same size, were added to provide an identical mass/volume ratio to that in the test flask.

At specified times, $100 \mu \mathrm{l}$ was taken from the "hydrolysis tube," put into ice, and thereafter, all procedures were performed in the cold. $100 \mu 1$ of $6 \mathrm{~N}$ perchloric acid was added to the $100-\mu \mathrm{l}$ aliquot, mixed, and centrifuged at 20,$000 \mathrm{~g}$ for $5 \mathrm{~min}$ at $4^{\circ} \mathrm{C}$. To $100 \mu \mathrm{l}$ of the supernate, $400 \mu \mathrm{l}$ of cold $P_{1}$ solution (144.2 $\mathrm{mg}$ anhydrous $\mathrm{Na}_{2} \mathrm{HPO}_{4} / 100 \mathrm{ml}$ distilled water) and $1.0 \mathrm{ml}$ of cold $\mathrm{PP}_{1}$ solution $(12.8 \mathrm{mg}$ $\mathrm{Na}_{4} \mathrm{P}_{2} \mathrm{O}_{7} \cdot 10 \mathrm{H}_{2} \mathrm{O} / 100 \mathrm{ml}$ distilled water) were added. Next $1.5 \mathrm{ml}$ of reagent $\mathrm{A}(13.4 \mathrm{ml} 5 \mathrm{~g} / 100 \mathrm{ml}$ ammonium molybdate $+3.6 \mathrm{ml} 15 \mathrm{~N} \mathrm{H}_{2} \mathrm{SO}_{4}+3.0 \mathrm{ml} \mathrm{H}_{2} \mathrm{O}$ ) was added and thoroughly mixed. $1 \mathrm{ml}$ of this was added to $10 \mathrm{ml}$ of 0.5 $\mathrm{N} \mathrm{HCl}$ for counting (total counts $T$ ) using Cerenkov emission and a Packard Tri-Carb liquid scintillation counter, model 3320 (Packard Instrument Co., Inc., Downers Grove,
III.). The efficiency of this counting technique was approximately $50 \% .2 \mathrm{ml}$ of reagent $\mathrm{B}$ (four parts isobutanol + one part petroleum ether) was added to the remaining solution and mixed for exactly $1 \mathrm{~min}$.

After centrifugation at $1,000 \mathrm{~g}$ for $5 \mathrm{~min}, 1 \mathrm{ml}$ from the upper layer $(U)$ was counted in $10 \mathrm{ml}$ of isobutanol, and $1 \mathrm{ml}$ from the lower layer $(L)$ was counted in $10 \mathrm{ml}$ of $0.5 \mathrm{~N} \mathrm{HCl}$. By this method, $\mathrm{P}_{1}$ was extracted into the isobutanol layer and the percentage of hydrolysis of $\mathrm{PP}_{1}$ to $\mathrm{P}_{1}$ was calculated thus: percent hydrolysis $\mathrm{PP}_{1}=(\mathrm{cpm} /$ $\mathrm{ml} U \times 0.8 \times 100) /(\mathrm{cpm} / \mathrm{ml} U+L)$. The factor 0.8 was used to correct for the increased efficiency of counting in isobutanol.

In one experiment, the effect of hydrolysis was examined by adding approximately $2 \mathrm{U}$ of inorganic pyrophosphatase (type III, Sigma Chemical Co., St. Louis, Mo.) to the incubation solution containing $2 \mathrm{mg} / 100 \mathrm{ml}$ of $\mathrm{Mg}^{++}$.

Microbial contamination. As many bacteria and fungi possess pyrophosphatases, it was essential to eliminate such contamination. Hence, penicillin, streptomycin, and amphotericin were added to all incubation solutions routinely as described above. At the end of each experiment, a small aliquot of the incubation material was transferred under full sterile conditions to a nutrient agar plate. Contamination occurred in about $5 \%$ of experiments and such results were discarded.

\section{RESULTS}

Verification of methods. Fig. 1 shows the result of the experiment designed to ascertain whether any microcrystals were escaping through the $0.45-\mu \mathrm{m}$ Millipore filter. There were $1,689 \mathrm{cpm}$ in $200 \mu \mathrm{l}$ of the unprocessed filtrate. After centrifugation of another 300 $\mu 1$ of the same filtrate, there were $1,702 \mathrm{cpm}$ in the upper $200 \mu 1$ layers, making it unlikely that any crysals had leaked through. There were $1,546 \mathrm{cpm}$ in $200 \mu \mathrm{l}$ of the upper layer at the $\mathrm{CCl}_{4}$ (aqueous phase). The miscibility of $\mathrm{CCl}_{4}$ in $\mathrm{H}_{2} \mathrm{O}$ is only $0.7 \%$. $^{2}$ There were only $30 \mathrm{cpm}$ in the denser carbon tetrachloride. If microcrystals had escaped through the filter, they would have been deposited in the $\mathrm{CCl}_{4}$ layer after centrifugation, as shown in the control experiment, when without prior filtration there were $2,205 \mathrm{cpm}$ in the $\mathrm{CCl}_{4}$.

A comparison of the solubility in Tris buffer of radioactive and nonradioactive CPPD crystals is illustrated in Fig. 2. Both crystals achieved a similar final solubility, although the data for the nonradioactive CPPD crystals showed greater variability than did the corresponding values derived by counting ${ }^{45} \mathrm{Ca}$. The inset graph demonstrates the correlation between the two methods. The calculated specific activities were virtually constant, showing that the crystals were uniformly labeled with ${ }^{45} \mathrm{Ca}$.

In the isotopic exchange experiment in which 0.2 $\mu$ mol of ${ }^{45} \mathrm{Ca}$ was allowed to "equilibrate" with 44.82 $\mu \mathrm{mol}$ of CPPD crystals in $5 \mathrm{ml}$ of Tris- $\mathrm{HCl}$ buffer for $48 \mathrm{~h}$, the respective specific activities of the filtered CPPD crystals at $4,9,25$, and $48 \mathrm{~h}$ were: $0.19,0.26$,

\footnotetext{
${ }^{2}$ Personal unpublished observation.
} 


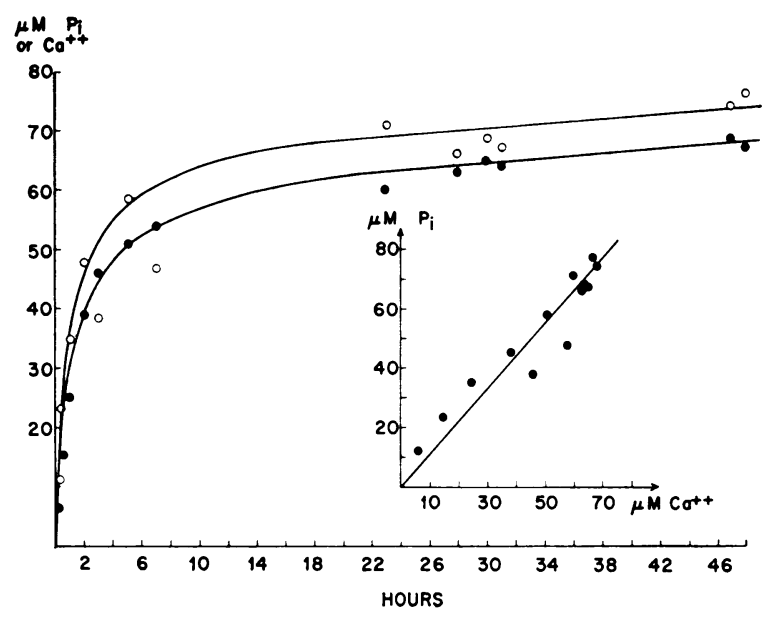

Figure 2 Comparison of solubility of CPPD crystals size 20-37 $\mu \mathrm{m}$ in Tris- $\mathrm{HCl} 0.1 \mathrm{M} \mathrm{pH} 7.4,37^{\circ} \mathrm{C}$ measured both colorimetrically as $\mathrm{P}_{1}(\bullet)$ and isotopically as $\mathrm{Ca}(\mathrm{O})$, expressed as micromolar concentration. The inset shows the correlation between solubilities of the two preparations measured at different times.

0.25 , and $0.27 \mu \mathrm{Ci} / \mu$ mol. Thus, it appeared that after $9 \mathrm{~h}$ no measurable isotope exchange occurred. As the specific activity of the added carrier-free ${ }^{45} \mathrm{Ca}$ was 26 $\mu \mathrm{Ci} / \mu \mathrm{mol}$, the exchange of $\mathrm{Ca}$ for ${ }^{45} \mathrm{Ca}$ on a molar for molar basis was $0.5 \%$ at an equilibrium time of $9 \mathrm{~h}$.

Effect of crystal size. Smaller crystals with a larger surface area to volume ratio dissolved more quickly than large crystals (Fig. 3). As expected, the final solubility approached a uniform value. As this is an important

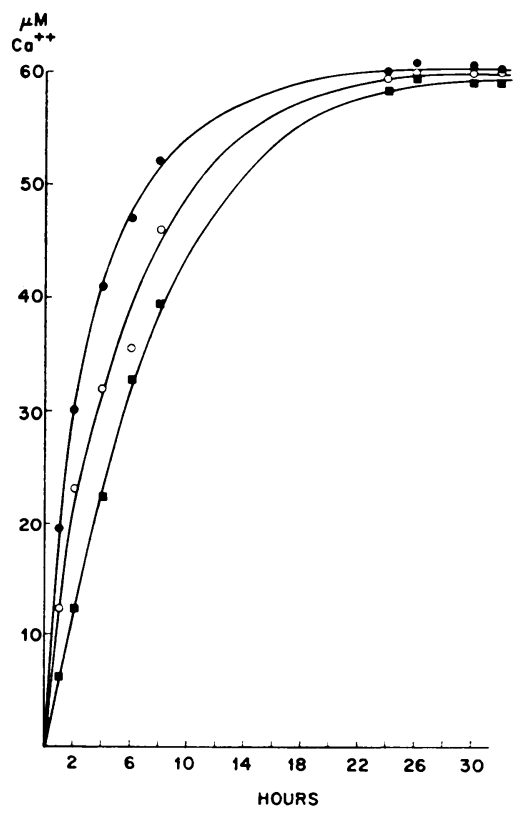

Figure 3 Effect of crystal size on the rate of dissolution in Tris- $\mathrm{HCl}$ buffer, $\mathrm{pH} 7.4,37^{\circ} \mathrm{C}$ ( (๑) $<20 \mu \mathrm{m}$ (O)

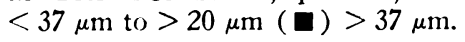

variable, all subsequent experiments were performed with the crystals sized $20-37 \mu \mathrm{m}$, as these are representative of the majority of cartilaginous CPPD crystals.

Effect of $p H$ and ionic strength. Final solubilities reached after $48 \mathrm{~h}$ incubation in $0.2 \mathrm{M}$ glycine buffer of varying $\mathrm{pH}$ are shown in Fig. 4. Between $\mathrm{pH} 8$ and 6 , there is an almost linear rise in solubility, with a value of $38 \mu \mathrm{M}$ at $\mathrm{pH} 7.4$, which is a similar value to that found in $\mathrm{SP}$ at $\mathrm{pH}$ 9.0, after which it again increases with increasing $\mathrm{pH}$.

Increasing the ionic strength by the addition of sodium chloride caused a moderate increase in solubility. This experiment was performed in $0.05 \mathrm{M}$ phosphate buffer $\mathrm{pH} 7.4$ which itself has an ionic strength of 0.15 , and this must be added for absolute values.

Common ion effect. Ionized calcium concentration has a marked effect on solubility (Fig. 5). This experiment was done in SP and it is noted that the final solubility with no added calcium is $20 \mu \mathrm{M}$ lower than in $0.1 \mathrm{M}$ Tris- $\mathrm{HCl}$ buffer. In the range between 14 and $5 \mathrm{mg} / 100 \mathrm{ml}$, there is little change, but at lower concentrations there was a progressive increase in solubility.

The other common ion, $\mathrm{PP}_{1}$ (Fig. 6), had unexpected effects on solubility; on an equimolar basis, up to a concentration of about $500 \mu \mathrm{M}$, it had a more marked depressant effect on solubility than does $\mathrm{Ca}^{++}$although, in

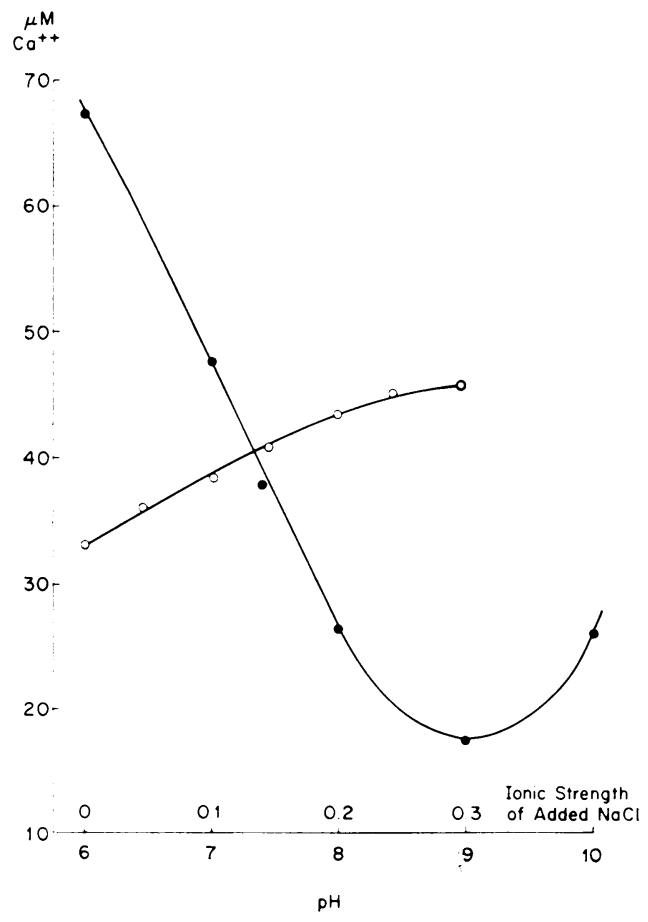

Figure 4 Effect of $\mathrm{pH}$ (๑) on solubility in a glycine $\mathrm{HCl} / \mathrm{NaOH}$ buffer, $0.2 \mathrm{M}$, and effect of ionic strength ( $\mathrm{O}$ ) in phosphate $0.05 \mathrm{M}, \mathrm{pH}$ 7.4. Both experiments performed at $37^{\circ} \mathrm{C}$. 


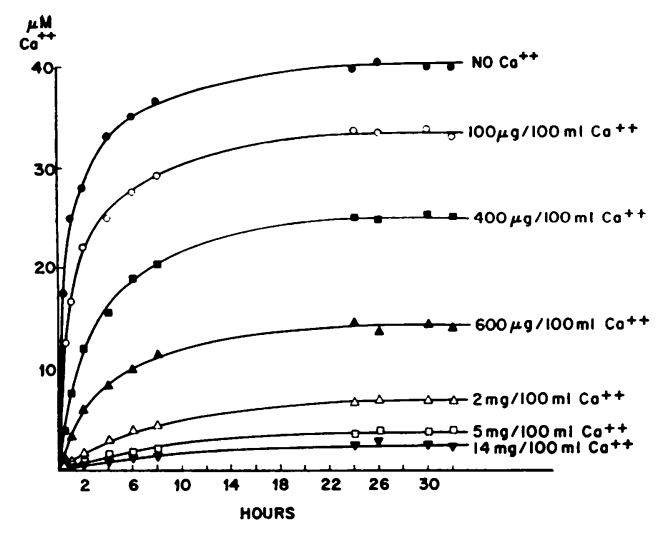

FIGURE 5 Effect of ionized calcium on solubility of CPPD crystals. Performed in a protein-free $\mathrm{SP}, \mathrm{pH} 7.4,37^{\circ} \mathrm{C}$.

the usual concentrations found in synovial fluid (2-25 $\mu \mathrm{M})$, it had little effect on solubility. As its concentration increased above $1,000 \mu \mathrm{M}$, it had a progressive solubility-enhancing effect, possibly due to $\mathrm{Ca}^{++}$chelation.

In a similar experiment, a modest increase in solubility was found with increasing concentration of $\mathrm{P}_{1}$; namely, a solubility of $44 \mu \mathrm{M}$ at a $P_{1}$ concentration of 1 $\mathrm{mM}$, increasing to $50 \mu \mathrm{M}$ at a $\mathrm{P}_{1}$ concentration of 50 $\mathrm{mM}$.

Effect of hydrolysis. The hydrolysis of $\mathrm{PP}_{1}$ lead to increased solubility. When yeast pyrophosphatase was added to Tris- $\mathrm{HCl}$ buffer containing $2 \mathrm{mg} / 100 \mathrm{ml}$ of $\mathrm{Mg}^{++}$, there was $100 \%$ hydrolysis in less than $1 \mathrm{~h}$ and a corresponding fivefold rise in solubility over the course of $30 \mathrm{~h}$ as compared to control (Fig. 7). No unhydro-

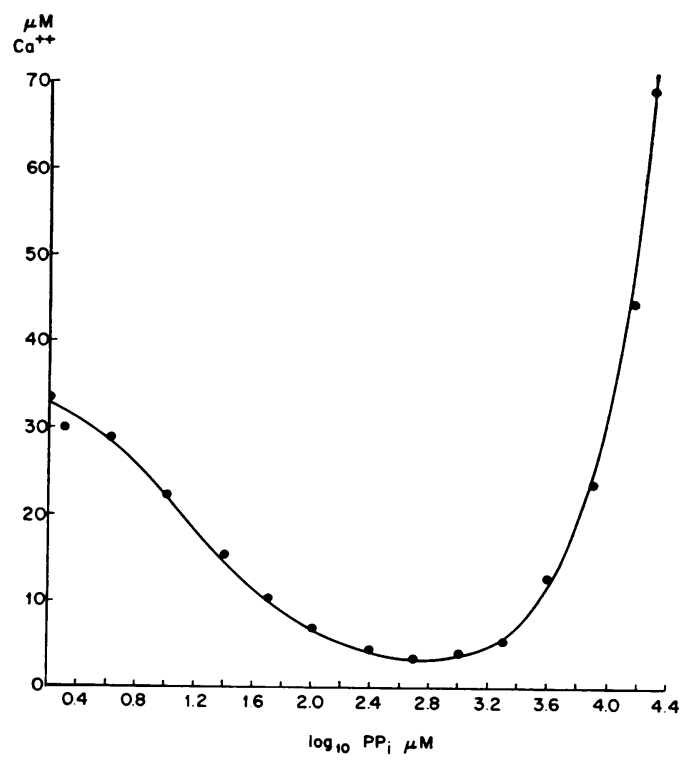

Figure 6 Effect of $\mathrm{PP}_{1}$ on solubility of CPPD crystals performed in a protein/calcium-free $\mathrm{SP} \mathrm{pH} 7.4,37^{\circ} \mathrm{C}$.

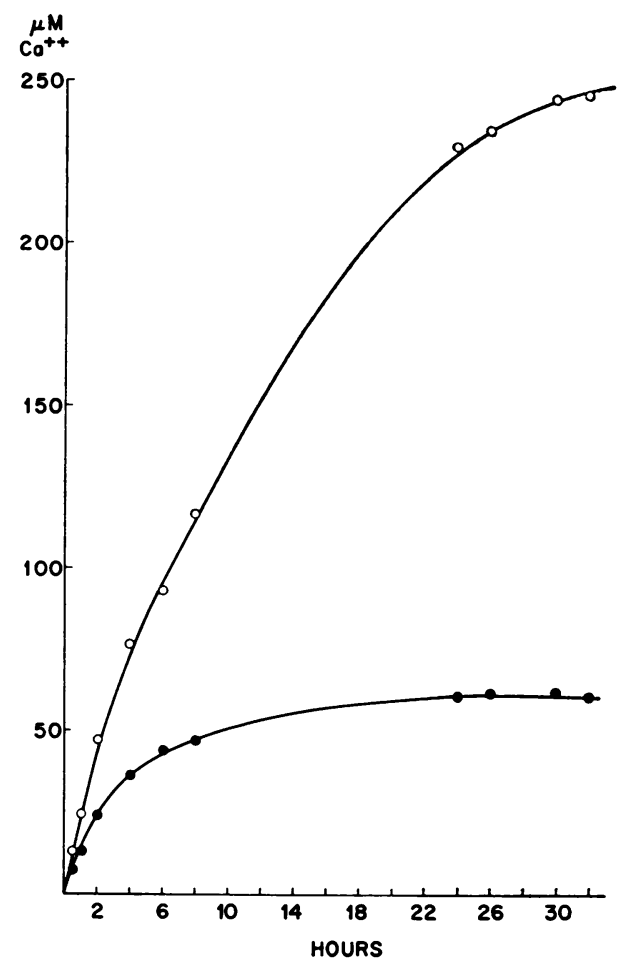

FIGURE 7 Effect of hydrolysis induced by $2 \mathrm{U}$ of yeast inorganic pyrophosphatase $(O)$ in a Tris-HCI buffer, 0.1 $\mathrm{M}$, pH 7.4 plus $2 \mathrm{mg} / 100 \mathrm{ml} \mathrm{Mg}^{++}, 37^{\circ} \mathrm{C} ; 100 \%$ hydrolysis occurred within $1 \mathrm{~h}$ while in the control experiment, without pyrophosphatase (๑) $20 \%$ hydrolysis was achieved after $30 \mathrm{~h}$ in the control.

lyzed $\mathrm{PP}_{1}$ was found at any subsequent time in the flask containing the enzyme.

Equilibrium had not been achieved even after $30 \mathrm{~h}$ incubation, and it is probable that the slight upward slope, noted in all of our figures is a result of continuing hydrolysis. Measurements of hydrolysis made in all experiments at 24 and $48 \mathrm{~h}$, showed no values greater than $30 \%$ at $48 \mathrm{~h}$, the mean value being $24 \%$. Based on the results of this experiment, it is unlikely that this degree of hydrolysis significantly influenced the observed final solubility.

Effect of protein. When dialyzed human serum albumin having a calcium concentration of $0.3 \mathrm{mg} / 100 \mathrm{ml}$ was added to SP (final protein concentration $5 \mathrm{~g} / 100$ $\mathrm{ml}$ ) and $\mathrm{Ca}^{++}$added to a final concentration of 3,1 , and $0.8 \mathrm{mg} / 100 \mathrm{ml}$ (Fig. 8), it is seen that there was an apparent increase in solubility when compared to the same concentration of $\mathrm{Ca}^{++}$in the absence of protein (Fig. 5). When equilibrium dialysis was performed after $48 \mathrm{~h}$ incubation, the diffusible ${ }^{3}$ calcium values are seen to be $1.98,1.6$, and $0.26 \mathrm{mg} / 100 \mathrm{ml}$, respectively. Thus the

${ }^{3}$ Diffusible calcium levels are assumed to approximate the ionized calcium concentrations here and elsewhere in this paper. 


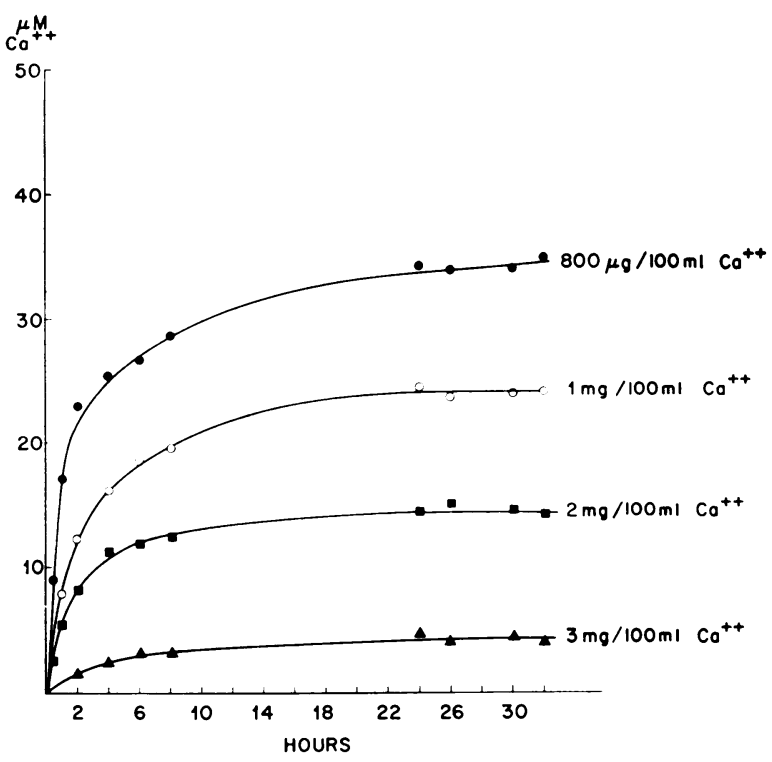

FIgUre 8 Effect of CPPD crystal solubility of adding human serum albumin (dialyzed to remove most of its bound calcium) in a final concentration of $5 \%$ to proteinfree SP and then returning known amounts of calcium to the solution. Performed at $\mathrm{pH} 7.4,37^{\circ} \mathrm{C}$. Equilibrium dialysis against the SP was then performed on aliquots of each solution at $48 \mathrm{~h}$, and the distribution of calcium measured.

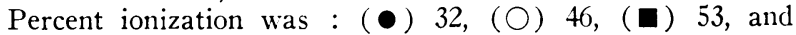
(A) 66 .

solubility-enhancing effect of albumin is entirely due to calcium binding according to the equilibrium:

$n \mathrm{Ca}^{++}+m \mathrm{Alb} \rightleftharpoons x(\mathrm{Alb}-\mathrm{Ca})+(m-x) \mathrm{Alb}+$

$$
(n-x) \mathrm{Ca}^{++} \text {, }
$$

where $n \mathrm{Ca}^{++}$and $m$ Alb represent the original molar concentration of free calcium and albumin, an " $x$ " represents the molar concentration of the albumin-calcium complex.

Two randomly selected synovial fluids, from patients with pseudogout and rheumatoid arthritis, respectively, displayed a similar dependence of solubility on ionized calcium. The calcium contents before and after dialysis, solubilities at $48 \mathrm{~h}$ of incubation, and diffusible calcium values at $48 \mathrm{~h}$ of incubation (derived from equilibrium dialysis) are shown in Table I. When the calcium is removed, the solubility increased markedly; the individual levels were those predicted from the data Fig. 5, suggesting ionized calcium is the major determinant of CPPD crystal solubility. A similar phenomenon was seen when calcium was returned to the system, the final solubility was of the order of magnitude predicted from the data shown in Fig. 5. Actual measurements were of diffusible calcium; ionized calcium levels are probably somewhat lower.

Effect of magnesium and citrate. Magnesium is selectively concentrated within cells to a concentration of
$45 \mathrm{meq} /$ liter (reference 17, p. 3 ) and hence $\mathrm{Mg}^{++}$levels are likely to be elevated in stored blood. The finding of an enhanced solubility on the addition of $\mathrm{Mg}^{++}$ions is therefore of some interest (Fig. 9). Likewise citrate, a constituent of ACD (acid citarte dextrose) solution used in anticoagulating stored blood has an appreciable effect on solubility (Fig. 10) depending on its concentration. In this particular example, the concentrations of sodium citrate expected when $5 \mathrm{U}$ of blood stored in ACD solution is distributed in volumes of 5 liters (intravascular), 15 liter (extravascular), and 45 liters (total body water), were used arbitrarily.

Diffusible calcium in synozial fluid. In view of the demonstrated effect of increased solubility at ionized calcium values below $5 \mathrm{mg} / 100 \mathrm{ml}$, it was of some importance to know what percentage of total calcium in synovial fluid is diffusible. Similar results were obtained by both the chemical and radioactive methods in 10 assorted synovial fluids; the mean value being $39.5 \%$ (Table II). This compares with a value of approximately $60 \%$ in plasma (reference 17 , p. 311 ).

\section{DISCUSSION}

In this study we have equated the solubility of CPI'D crystals with the molar concentration of ${ }^{45} \mathrm{Ca}$ in solution. This is not a true solubility in the terms of ionic activities, or a true solubility product, as only the $\mathrm{Ca}^{++}$concentration and not both $\mathrm{Ca}^{++}$and $\mathrm{PP}_{1}$ was being measured. In our "verification of methodology," it is seen that $\mathrm{PP}_{1}$ values (derived from $\mathrm{P}_{1}$ measurements) closely correspond to $\mathrm{Ca}^{++}$values (Fig. 2) as would be expected from the law of mass action:

$$
\mathrm{Ca}_{2} \mathrm{P}_{2} \mathrm{O}_{7} \rightleftharpoons 2 \mathrm{Ca}^{++} \mathrm{P}_{2} \mathrm{O}_{7} \ldots-\cdots
$$

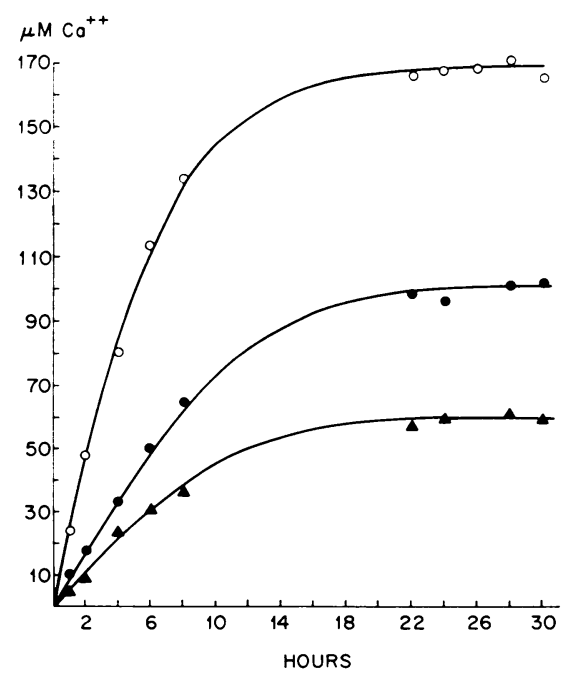

Figure 9 Effect of $\mathrm{Mg}^{++}$on the solubility of CPPD crystals. Performed in Tris $\mathrm{HCl} 0.1 \mathrm{M} \mathrm{pH} 7.4,37^{\circ} \mathrm{C}$. (O)

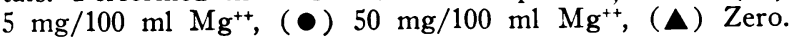


TABLE I

CPPD Solubility in Synovial Fluid, Effects of Calcium

\begin{tabular}{|c|c|c|c|c|c|c|}
\hline \multirow[b]{2}{*}{$\begin{array}{c}\text { Measured and derived } \\
\text { values }\end{array}$} & \multicolumn{3}{|c|}{ PG* Synovial fluid } & \multicolumn{3}{|c|}{$\mathrm{RA}^{*}$ Synovial fluid } \\
\hline & Undialyzed & Dialyzed & $\begin{array}{c}\text { Dialyzed plus } \\
4.4 \mathrm{mg} / 100 \mathrm{ml} \\
\mathrm{Ca}\end{array}$ & Undialyzed & Dialyzed & $\begin{array}{c}\text { Dialyzed plus } \\
4.4 \mathrm{mg} / 100 \mathrm{ml} \\
\mathrm{Ca}\end{array}$ \\
\hline $\begin{array}{l}\text { Total calcium, } \\
m g / 100 m l\end{array}$ & 7.2 & 0.56 & 5.0 & 8.6 & 0.48 & 5.0 \\
\hline $\begin{array}{l}\text { Solubility at } 48 \mathrm{~h} \\
\qquad \mu M^{45} \mathrm{Ca}\end{array}$ & 7.5 & 42.9 & 8.9 & 5.0 & 31.3 & 3.7 \\
\hline $\begin{array}{l}\text { Diffusible } \mathrm{Ca} \text { at } 48 \mathrm{~h} \text {, } \\
\quad \%\end{array}$ & 21 & 24 & 44 & 24 & 26 & 47 \\
\hline $\begin{array}{l}\text { Calculated diffusible } \mathrm{Ca} \text {, } \\
\quad m g / 100 \mathrm{ml}\end{array}$ & 1.52 & 0.134 & 2.2 & 2.06 & 0.125 & 2.35 \\
\hline
\end{tabular}

* PG, pseudogout; RA, rheumatoid arthritis.

As our measured values behave in a way predicted by the law of mass action and as the crystals were uniformly labeled, it is reasonable to assume the validity of $\mathrm{PP}_{1}$ concentration as derived from ${ }^{45} \mathrm{Ca}$ measurements. The solubility of a slightly soluble salt $\left(K_{\text {op }}\right)$ such as $\mathrm{Ca}_{2} \mathrm{P}_{2} \mathrm{O}_{7} \cdot 2 \mathrm{H}_{2} \mathrm{O}$ is given by :

$$
K_{s p}=\frac{\left[\mathrm{Ca}^{++}\right] 2\left[\mathrm{P}_{2} \mathrm{O}_{7}\right]}{\left[\mathrm{Ca}_{2} \mathrm{P}_{2} \mathrm{O}_{7}\right]} .
$$

As the active mass of the minimally soluble $\mathrm{Ca}_{2} \mathrm{P}_{2} \mathrm{O}_{7}$ is

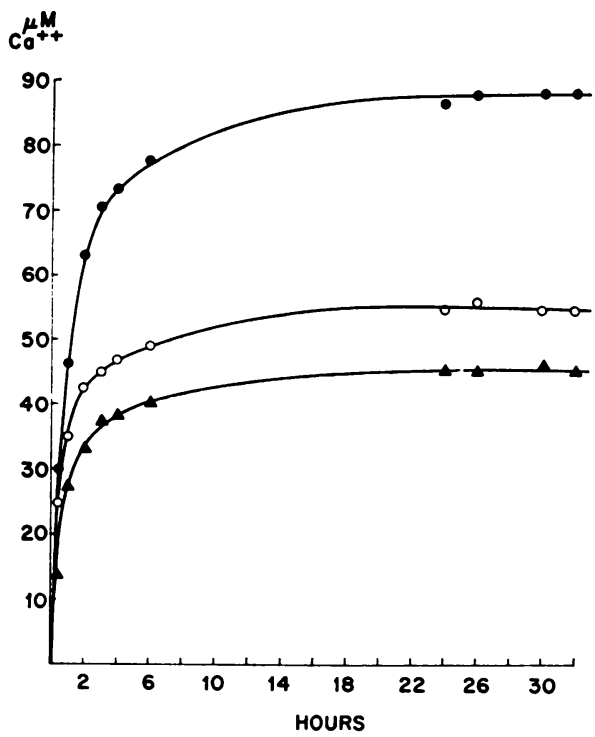

FIgURE 10 Solubility-enhancing effect of citrate on CPPD crystals in protein and calcium-free $\mathrm{SP}, \mathrm{pH} 7.4,37^{\circ} \mathrm{C}$. Citrate concentration was adjusted to that found in 5 liters of blood stored in ACD solution distributed ( $\bullet$ ) intravascularly (citric acid $20.6 \mathrm{mg}+$ sodium citrate $160 \mathrm{mg} / 100$ $\mathrm{ml} \mathrm{SP}$ ). (O) extracellularly (citric acid $6.9 \mathrm{mg}+$ sodium citrate $53.3 \mathrm{mg} / 100 \mathrm{ml} \mathrm{SP}$ ) (A) total body water (citric acid $0.52 \mathrm{mg}+$ sodium citrate $20 \mathrm{mg} / 100 \mathrm{ml} \mathrm{SP}$ ). very small and constant the solubility product is given by the product $(18)$ :

$$
K_{s p}=[\mathrm{Ca}]^{2} \cdot\left[\mathrm{P}_{2} \mathrm{O}_{7}\right] .
$$

As we are measuring only the calcium concentration and by the law of mass action the $\mathrm{PP}_{1}$ concentration is directly related: in our system $K_{\imath p}=[\mathrm{Ca}]^{3}$. We have chosen to use the concentration of crystal-derived calcium as an index of solubility. This is obviously directly proportional to a derived $K_{s p}$, but avoids making any of the above assumptions.

In those experiments in which there was added calcium in the incubation medium, the isoionic exchange of cold calcium with the ${ }^{45} \mathrm{Ca}$-labeled CPPD crystals will lead to some error in our calculated solubilities. In our isotope-exchange experiment, approximately $0.5 \%$ of calcium in the incubation medium exchanged with crystal-derived calcium. This implies that the true solubilities, in experiments containing exogenous calcium,

TABLE II

Diffusible Calcium in Synorial Fluids*

\begin{tabular}{lcc}
\hline Synovial fluid source & $\begin{array}{c}\text { Atomic } \\
\text { absorption }\end{array}$ & Radioactive \\
\hline Osteoarthritis & 45 & $\%$ \\
Osteoarthritis & 42 & 43 \\
Osteoarthritis & 27 & 41 \\
Rheumatoid arthritis & 42 & 29 \\
Rheumatoid arthritis & 43 & 41 \\
Pseudogout & 44 & 44 \\
Pseudogout & 43 & 43 \\
Gout & 35 & 35 \\
Traumatic & 35 & 34 \\
Traumatic & 40 & 41 \\
\hline
\end{tabular}

* Equilibrium dialysis against calcium-free SP ultrafiltrate, $37^{\circ} \mathrm{C}$, pH 7.4 . 
are probably somewhat higher than the observed values; but with an isoionic exchange of only $0.5 \%$ after $9 \mathrm{~h}$ of incubation, this error is negligible.

Our results are generally in agreement with the previous preliminary report from this laboratory on the solubility of synthetic CPPD crystals (7), namely, the solubility-enhancing effects of protein and magnesium ions and depressant effect of inorganic orthophosphate $\left(P_{1}\right)$ : in fact, $\mathrm{P}_{1}$ increased solubility to the degree expected by an increase in ionic strength. Our data indicate that the solubility-enhancing effect of protein results from calcium-ion binding with a fall in the concentration of free calcium.

The effects of altering the concentrations of $P_{1}$ and $\mathrm{Ca}^{++}$on the solubility of CPPD crystals were of interest. On a molar basis at low concentrations, $\mathrm{PP}_{1}$ had a greater solubility-depressant effect than did $\mathrm{Ca}^{++}$. With decreasing concentrations of $\mathrm{Ca}^{++}$from levels actually found in synovial fluid, solubility was markedly enhanced while a decrease in $\mathrm{PP}_{1}$ concentration had relatively little effect. Such effects are probably a function of their physiologic concentrations, as the $\mathrm{PP}_{1}$ level in synovial fluids is only 2-25 $\mu \mathrm{M}$ (6-9), whereas, the ionized calcium level has a mean value of $3.5 \mathrm{mg} / 100 \mathrm{ml}$, this is 17-370 times greater (7). Moreover, much of the PP, in solution is in the form of $\mathrm{MeP}_{2} \mathrm{O}_{i}$ rather than as $\mathrm{P}_{2} \mathrm{O}_{7}^{----}$, where $\mathrm{Me}^{++}$refers to divalent cations (chiefly $\mathrm{Mg}$ ).

We have shown that factors which increase the solubility of CPPD crystals lead to an acute inflammatory episode of pseudogout (10). We have termed this hypothetical process "crystal shedding" as CPPD crystals embedded in the articular cartilage become smaller until, loosened from their mold of matrix, they float freely into the joint cavity. Thus, the level of ionized calcium appears to be the most important regulator of CPPD dissolution. Within the range of $14-5 \mathrm{mg} / 100 \mathrm{ml}$ there is relatively little effect on solubility, but with levels below $5 \mathrm{mg} / 100 \mathrm{ml}$, a rapid increase in solubility occurs.

It is tempting to speculate that postoperative attacks of pseudogout (19), especially those after parathyroidectomy (20), result from the depression of ionized calcium actually attained in synovial fluid; Is the depression of $\mathrm{Ca}^{++}$during surgery of sufficient magnitude to induce crystal shedding? The diffusible calcium in 10 randomly selected synovial fluids was about $40 \%$ of the total, as compared to an ionized plasma level of $60 \%$ (reference 17 , p. 311), and the total calcium concentration of synovial fluid is lower than in plasma. Calculated synovial fluid-ionized calcium levels (obtained with a calcium electrode), from the published figures of McCarty et al. (7), give a mean of $3.5 \mathrm{mg} / 100 \mathrm{ml}$, or $41 \%$ of the total calcium concentration in synovial fluid.

These findings indicate there is a gradient in the level of ionized calcium between plasma (60\% ionized) and synovial fluid (40\% ionized). The level of diffusible calcium will be somewhat higher due to complexing with ultrafiltrable substances such as citrate, but this only accounts for approximately $0.5 \mathrm{mg} / 100 \mathrm{ml}$ (14). We assume this ionized calcium gradient is due to "additional binding" by, as yet, unidentified substances in synovial fluid. This property of synovial fluid may be of critical importance in the etiology of the postoperative attack of pseudogout, bearing in mind the rapid increase in CPPD solubility below an ionized calcium level of 5 $\mathrm{mg} / 100 \mathrm{ml}$, as is seen in the following example:

For a patient undergoing a major surgical procedure, it has been shown the mean fall in ionized calcium is $73 \%$ (21) towards the end of the operation, returning slowly towards normal by the 4th postoperative day. Hence, a patient with a total plasma calcium of $10 \mathrm{mg} /$ $100 \mathrm{ml}$ would have an ionized level of $6 \mathrm{mg} / 100 \mathrm{ml}$ (assuming $60 \%$ of total is ionized in plasma) and this would be reflected by a synovial fluid-ionized calcium not greater than $4 \mathrm{mg} / 100 \mathrm{ml}$. If the plasma-ionized $\mathrm{Ca}^{++}$ level were reduced $73 \%$, it would fall to $4.38 \mathrm{mg} / 100$ $\mathrm{ml}$ and the corresponding synovial fluid level would drop to $2.92 \mathrm{mg} / 100 \mathrm{ml}$.

The increased CPPD crystal solubility during surgery will be augmented by blood transfusion as shown by the experiments with citrate (the main constituent of anticoagulation mixtures used in stored blood) and magnesium (which is elevated in stored blood).

CPPD crystals take $12 \mathrm{~h}$ or more to reach equilibrium with common ions in the surrounding liquid. This is of importance relative to the origin of synovial fluid $\mathrm{PP}_{1}$, which is higher than plasma $\mathrm{PP}_{\mathfrak{}}(8,9)$, suggesting local production. $\mathrm{PP}_{1}$ could result from metabolism within cartilage, subchondral bone, or synovial membrane cells, or from dissolution of CPPD crystals embedded in the cartilage or free in the synovial fluid. Recent work has shown a mean turnover of $102 \% / \mathrm{h}$ for the intra-articular $\mathrm{PP}_{1}$ pool in chronic pseudogout and even higher values in more acute inflammation and in rheumatoid joints (22). Therefore, CPPD crystal dissolution does not contribute significantly to the $\mathrm{PP}_{1}$ levels found in synovial fluid.

It has been suggested that a lower than normal activity of inorganic pyrophosphatase in joint tissue could account for the higher PP$P_{1}$ levels in the synovial fluid in pseudogout than in controls (23). The case reported by O'Duffy (24) of coincident hypophosphatasia and pset1dogout supports such a hypothesis, as there is good evidence that alkaline phosphatase is a pyrophosphatase (25-27). A reduced activity of glucose-6-phosphate pyrophosphate phosphotransferase was found in the joint fluid of patients with both gout and pseudogout, as compared to rheumatoid arthritis (28), while Russell and coworkers found a significantly reduced level of alkaline phosphatase activity in pseudogout synovial fluid com- 
pared to fluids from other patients with different types of arthritis, but we found no such difference in synovial fluid alkaline phosphatase levels (6). Pyrophosphatase activity markedly augments the solubility of CPPD crystals. Theoretically, in the acute attack of pseudogout, neutrophil leukocyte phosphatases may be released and accelerate the shedding of crystals. However, actual synovial fluid $\mathrm{PP}_{1}$ hydrolysis rates in acute and chronic pseudogout showed no significant difference (22).

The decrease in joint fluid $\mathrm{pH}$ which accompanies inflammatory arthritis (29) may augment CPPD crystal dissolution and shedding. Crystal size may also be important, influencing crystal shedding as the smaller the crystals, the more rapid its dissolution rate (Fig. 3).

\section{ACKNOWLEDGMENTS}

The authors are indebted to Susan Loresco and Young Park for their excellent technical assistance.

This work was supported by U. S. Public Health Service grant AM 13069 and by a grant from the Illinois Chapter of the Arthritis Foundation.

\section{REFERENCES}

1. McCarty, D. J., Jr., N. N. Kohn, and J. S. Faires. 1962. The significance of calcium phosphate crystals in the synovial fluid of arthritic patients: the "pseudogout syndrome." I. Clinical aspects. Ann. Intern. Med. 56: 711-737.

2. Schumacher, H. R., and P. Phelps. 1971. Sequential changes in human polymorphonuclear leukocytes after urate crystal phagocytosis. An electron microscopic study. Arthritis Rheum. 14: 513-526.

3. Andrews, R., and P. Phelps. 1971. Release of lysosomal enzymes from polymorphonuclear leukocytes (PMN) after phagocytosis of monosodium urate (MSU) and calcium pyrophosphate dihydrate (CPPD) crystals: effect of colchicine and indomethacin. Arthritis Rheum. $14: 368$. (Abstr.)

4. Bywaters, E. G. L., A. St. J. Dixon, and J. T. Scott. 1963. Joint lesions of hyperparathyroidism. Ann. Rheum. Dis. 22 : 171-187.

5. Hamilton, E., R. Williams, K. A. Barlow, and P. M. Smith. 1968. The arthropathy of idopathic haemochromatosis. Q. J. Med. 37: 171-182 + plates 12-15.

6. Russell, R. G. G., S. Bisaz, H. Fleisch, H. L. F. Currey, H. M. Rubinstein, A. A. Dietz, I. Boussina, A. Micheli, and G. Fallett. 1970. Inorganic pyrophosphate in plasma, urine, and synovial fluid of patients with pyrophosphate arthropathy (chondrocalcinosis or pseudogout). Lancet. 2 : 899-902.

7. McCarty, D. J., S. D. Solomon, M. L. Warnock, and E. Paloyan. 1971. Inorganic pyrophosphate concentrations in the synovial fluid of arthritic patients. J. Lab. Clin. Med. 78 : 216-229.

8. Altman, R. D., O. E. Muniz, J. C. Pita, and D. S. Howell. 1973. Articular chondrocalcinosis. Microanalysis of pyrophosphate (PPi) in synovial fluid and plasma. Arthritis Rheum. 16: 171-178.

9. Silcox, D. C., and D. J. McCarty. 1974. Elevated inorganic pyrophosphate concentrations in synovial fluids in osteoarthritis and pseudogout. J. Lab. Clin. Med. 83: 518-531.

10. Bennett, R. M., J. R. Lehr, and D. J. McCarty. 1976. Crystal shedding and pseudogout-a hypothesis based on a therapeutic failure. Arthritis Rheum. In press.

11. Brown, E. H., J. R. Lehr, J. P. Smith, and A. W. Frasier. 1963. Preparation and characterization of some calcium pyrophosphates. J. Agric. Food Chem. 11: 214 222.

12. Phelps, P., A. D. Steele, and D. J. McCarty, Jr. 1968. Compensated polarized light microscopy. Identification of crystals in synovial fluid from gout and pseudogout. J. Am. Med. Assoc. 203: 508-512.

13. Gatter, R. A., and D. J. McCarty. 1967. Pathological tissue calcifications in man. Arch. Pathol. 84: 346-353.

14. Chen, P. S., Jr., T. Y. Toribara, and H. Warner. 1956. Microdetermination of phosphorus. Anal. Chem. 28: $1756-1758$.

15. Dittebrandt, M. 1948. Application of Weichselbaum biuret reagent to the determination of spinal fluid protein. Am. J. Clin. Pathol. 18: 439-441.

16. Brewer, J. M., A. J. Pesee, and R. R. Ashworth, editors. 1974. Experimental Techniques in Biochemistry. Prentice-Hall, Inc., Englewood Cliffs, N. J.

17. Campbell, E. J. M., C. J. Dickinson, and J. D. H. Slater. 1968. Clinical Physiology, Blackwell Scientific Publications, Ltd., Oxford. 3rd edition. 3, 311.

18. Angus, L. H. 1954. Physical Chemistry. University Tutorial Press Ltd., Cambridge. 242 pp.

19. O'Duffy, J. D. 1973. Pseudogout syndrome in hospital patients. J. Am. Med. Assoc. 226: 42-44.

20. Bilezikian, J. P., G. D. Aurbach, T. B. Connor, W. N. Pachas, A. Aptekar, S. A. Wells, J. Freijanes, and J. L. Decker. 1973. Pseudogout after parathyroidectomy. Lancet. 1 : 445-447.

21. Clowes, G. H. A., Jr., and F. A. Simeone. 1957. Acute hypocalcemia in surgical patients. Ann. Surg. 146: 530 541.

22. Camerlain, M., D. J. McCarty, D. C. Silcox, and A. Jung. 1975. Inorganic pyrophosphate pool size and turnover rate in arthritic joints. J. Clin. Invest. 55: 1373-1381.

23. Russell, R. G. G. 1972. Pyrophosphate metabolism and pseudogout. (Calcium pyrophosphate crystal deposition disease) 8th Symposium on Advanced Medicine. G. Neale, editor. Pitman Medical Publishing Co., Ltd., London. 380-396.

24. O'Duffy, J. D. 1970. Hypophosphatasia associated with calcium pyrophosphate dihydrate deposits in cartilage. Report of a case. Arthritis Rheum. 13: 381-388.

25. Cox, R. P., and M. J. Griffin. 1965. Pyrophosphatase activity of mammalian alkaline phosphatase. Lancet. 2: 1018-1019.

26. Cox, R. P., P. Gilbert, Jr., and M. J. Griffin. 1967. Alkaline inorganic pyrophosphatase activity of mammalian-cell alkaline phosphatase. Biochem. J. 105: 155161.

27. Eaton, R. H., and D. W. Moss. 1967. Alkaline orthophosphatase and inorganic byrophosphatase activities in human serum. Nature (Lond.). 214: 842-843.

28. Good, A. E., and W. H. Starkweather. 1969. Synovial fluid pyrophosphate phosphohydrolase (PPPH) in pseudogout, gout and rheumatoid arthritis. Arthritis Rheum. 12: 298. (Abstr.)

29. McCarty, D. J. 1974. Selected aspects of synovial membrane psysiology. Arthritis Rheum. 17: 289-296. 